\title{
Research on the Coordination Development of Money Market and Capital Market in China
}

\author{
Nanxi He ${ }^{1, a}$, Ruoyi Zhao ${ }^{2, b}$ \\ ${ }^{1}$ Shool of Economic \& Management, Southwest Jiaotong University, Chengdu, 611756, China \\ ${ }^{2}$ Shool of Economic \& Management, Southwest Jiaotong University, Chengdu, 611756, China \\ aemail:949198611@qq.com, bemail:510778096@qq.com
}

Keywords: Money Market; Capital Market; Coordinated Development; Uncoordinated Development; Securities Market

\begin{abstract}
Financial market is the link between the micro economy and macro economy. The government can control the country's economy through financial market. Money market and capital market are the important parts of the financial market, and the relationship of the two market influences the function of financial market. And weather the relationship of the two market is perfect or not, it has impacts on the national economic development. Only in the case of the mutual connection between the money market and the capital market, the overall function of the financial market can achieve the combination, which runs the entire financial system.

Firstly, this paper analyzes and compares the money market and capital market. This paper defines the concept from the aspects of the definition, difference, connection and function of the capital market and money market. This paper studies the difference and connection between the two market. Finally, the significance of the coordinated development is discussed.

Secondly, this paper briefly describes the current development of our capital market and money market. Key problems in the development of the two market are analyzed and compared. Finally, this paper summarizes the characteristics of the uncoordinated development of the capital market and the money market, and the main reasons of disequilibrium are presented.

Thirdly, through the analysis of some practical situations of our country's money market and capital market, this paper puts forward some suggestions on how to coordinate the development of the two market. The corresponding recommendations are proposed from the following two aspects: (1) Developing money market: extend the main body of the money market, and accelerate the development of credit asset securitization. (2) Regulating the development of capital market: accelerate the transformation of securities market development model, position the securities market function, broaden and develop the bond market.
\end{abstract}

\section{Introduction}

\section{1 The background and significance}

As the core of modern economy, finance is one of the standards of measuring the level of a country's development. Effective and mature financial market can mobilize and deploy social floating money, and promote savings converting to investment, which is important to promote economic growth. With the development of society, the structure of financial market tends to become more complex and hierarchical. As the most basic and the core of the financial market, the money market and capital market directly affect the development of financial markets.

And we know that the money market fund is conducive to accelerate the development of China's money market, and promote the coordinated development of the money market and capital market. Money market is the most basic of the financial system, and it will be difficult to establish a standardized and efficient capital market by a lack of standardized and developed money market. The development of current China's money market lags behind the capital market, which is not conducive for the balanced development of the financial market. The developed money market is a market with a variety of investment, a large size and complete functions of the market, and the generation of money market fund will be helpful to meet the above conditions. Therefore, it is of 
great significance to correctly understand the relationship between the capital market and the money market in China's macro-economy development. It is also important to study how to promote the coordination, health and improvement of the related government policies.

\subsection{The theoretical research results}

The strategy of "develop the capital market firstly, and then develop the money market" is implemented in the domestic financial market, and the institutional arrangement of "separate management, separate management" is adopted. This provision creates the obstacles and constraints for the communication between the money market and the capital market, which has aroused the attention of domestic scholars.

In the present study, the study for the two market is mainly on the development of the internal sub market. And the research on the coordination of the capital market and money market in China is started the last few years. Domestic scholars have increasingly stressed that the money market should be coordinated with the capital market development with the corresponding attention, because the development of the two market has an irreplaceable role in economic development.

The research on the money market in developing countries and economy transition countries is very little, mainly focusing on how the developing countries can raise fund from the money market. And the research on the capital market is mainly related to the issues of development. There is not much theory literature on the coordination development between the money market and the capital market.

\section{The Basic Theory of Coordination Development}

\subsection{Definition of concept}

\subsection{Definition of money market}

Money market is the market of short term fund, which refers to the financing period in one year, and this market is the important part of the financial market. The financial instruments in the market are mainly the short-term credit instruments issued by the government, banks and industrial and commercial enterprises, which have the characteristics of short term, strong liquidity and low risk. After the money supply level is divided into cash and deposit money, the short-term credit instrument is called "quasi-money". Therefore, this market is called "money market". Money market is the foundation of the capital market and the whole financial system, with three basic functions in the economic system as following: (1) to provide short-term liquidity; (2) to establish the benchmark interest rate for the entire financial system; (3) to provide market conditions for the implementation of monetary policy.

1.2 Definition of capital market

Capital market refers to the long-term capital market, which refers to the financing period over one year. The capital market includes the stock market, the long-term bond market and the long-term credit market. The main functions of the capital market in the economic system are: (1) to optimize the allocation of resources; (2) Financing function; (3) The formation of the capital price; (4) The formation of effective corporate governance.

\subsection{The distinction and connection between money market and capital market}

2.2.1 The distinction between money market and capital market

(1) The financing period of money market is generally less than one year, while the period of the capital market is over a year; (2) The main purpose of money market financing is to meet the demand for short-term liquidity, while the purpose of capital market financing is mainly to meet the long-term demand for fund; (3) The financial institutions of money market is mainly the commercial banks, while the financial institutions of capital market is mainly financing companies, enterprises, etc. (4) The interest rate in money market is short-term, while the interest rate in capital market is long-term; (5) The return of money market is relatively low, while the return of capital market is relatively high. (6) The risk of money market is smaller, while the risk of capital market is relatively large.

2.2.2 The connection between money market and capital market

There is close connection between money market and capital market, mainly in the following 
several aspects: (1) There are a lot of the same financial instruments; (2) The interest rate of the two market is very close; (3) There are a lot of same market participants; (4) Capital often flows to each other.

On the whole, the money market and capital market are part of the financial market, and it is the place where the financial assets are traded. The two market are closely related.

\subsection{The significance of the coordinated development between money market and capital market}

The coordinated development of the money market and the capital market includes two meanings as follows: First, the money market and the capital market itself are perfect. Second, the money market and the capital market are in cooperation and coordination. The coordination of the relationship between money market and capital market is of great significance in the key period of financial reform in China, and the main significance are shown as the following:

(1) Improving the financial market;

(2) Strengthening the implementation of monetary policy;

(3) It is conducive for the reform of interest rate market.

\section{Analysis on Uncoordinated Development}

\subsection{The Characteristics of uncoordinated development}

The uncoordinated development not only causes the problems of the circulation and benefit in money market and capital market, but also increases the cost burden of the national economy and the basic economic units, which results in incompetence of macro-control, soft constraint and low-efficiency supervision [1]. The main results are as follows:

(a) The scale of capital market expands faster than that of money market in China

The change of stock market sizes is listed in Table 1 from 2010 to 2014. The scale of the stock market is rapidly rising, and the speed is amazing.

Table.1. the change of stock market sizes from 2010 to 2014

\begin{tabular}{|cccccc|}
\hline $\begin{array}{c}\text { Listed companies } \\
\text { (amount) }\end{array}$ & $\mathbf{2 0 1 0}$ & $\mathbf{2 0 1 1}$ & $\mathbf{2 0 1 2}$ & $\mathbf{2 0 1 3}$ & $\mathbf{2 0 1 4}$ \\
$\begin{array}{c}\text { Opening accounts } \\
\text { (million) } \\
\text { Market value }\end{array}$ & 133.91 & 140.50 & 145.23 & 150.61 & 151.23 \\
$\begin{array}{c}\text { (trillion) } \\
\text { Market value/GDP (\%) }\end{array}$ & 26.54 & 21.48 & 23.04 & 23.91 & 37.25 \\
\hline
\end{tabular}

Table.2. the comparison of stock trading volume and GDP from 2003 to 2014 (Unit: trillion, \%)

\begin{tabular}{|cccc|}
\hline Year & Interbank Loan & GDP & Interbank Loan/GDP(\%) \\
\hline 2003 & 2.41 & 13.58 & 17.75 \\
2004 & 1.39 & 15.99 & 8.69 \\
2005 & 1.28 & 18.32 & 6.99 \\
2006 & 2.15 & 21.19 & 10.15 \\
2007 & 10.65 & 24.95 & 42.68 \\
2008 & 11.52 & 31.68 & 36.36 \\
2009 & 9.81 & 34.56 & 28.38 \\
2010 & 8.21 & 40.89 & 20.07 \\
2011 & 8.34 & 48.41 & 17.23 \\
2012 & 9.12 & 53.41 & 17.08 \\
2013 & 7.58 & 58.80 & 12.89 \\
2014 & 6.35 & 63.61 & 9.98 \\
\hline
\end{tabular}

From the point of view of the stock trading volume, regardless of the absolute value of the 
trading volume or comparison with GDP, the active degree from stock market was significantly higher than that from the interbank market.

(b) Uncoordinated Development of money market and capital market

(1) The uncoordinated development of money market

The disequilibrium of money market means that the money supply $\left(M_{s}\right)$ is not equal to money demand $\left(M_{d}\right)$. When $M_{s}$ is equal to $M_{d}$, the money market reaches the equilibrium.

(2) The uncoordinated development of capital market

This uncoordinated development mainly embodies as the imbalance of financing structure, which can restrict the healthy development of the financial market [2]. From the point of view of financing, the financing amount in bond market is significantly higher than that in stock market. From the internal development of the bond market, the domestic market is active, and corporate bond market is relatively small.

(c) The reasons for the dissevering development of money market and capital market

China doesn't pay enough attention to the money market and only focuses on the development of capital market. Because of the special situation of China, separate management and separate operation are implemented at the present stage, which results in serious disseverance in China's money and financial markets. In the end, the development of money market lags far behind the development of capital market.

(1) Pay attention to the investment functions and contempt policy functions.

The Central Banks in the market economy implements monetary policy mainly through the following methods:1) market manipulation; 2) rediscount policy; 3) The use of reserve requirements on deposit. The adoption of this measure will affect the $M d$ and market interest rates $\mathrm{r}$, which can meet the macro-economic targets. First of all, the peer lending market can promote the excess reserve fund of commercial banks at a relatively stable level, which creates a good condition for the money supply in the central bank [3]. Secondly, in order to achieve the ultimate goal of money policy, the central bank gets information feedback from the acceptance market by the implementation of the rediscount rate policy. In addition, with the continuous improvement of the acceptance market, the acceptance market continues to be stable. The market interest rate in equilibrium state can be formed, which can change with the market discipline and can be accepted by both the supply and demand. Finally, the central bank is in a proactive position in market manipulation, and the size of the macro economy is based on the need for free movements, which will not have a big impact on the money supply.

(2) Because China's capital market (as the main content of securities market) starts late, the current financial supervision implements "isolation" policy according to the requirements of separating management, and banks are prohibited from putting funds in the stock market.

(3) The lag of enterprise property right reform and the lack of social credit system

For the lag of property right reform, China's current commercial bill is mainly issued from the state-owned enterprises, the default behavior in acceptance of commercial bill has a serious impact on the credibility of commercial bill and brings some adverse social impacts. By the issue that these commercial bill enterprises have no independent property rights, in fact, they cannot really assume the responsibilities and obligations to fulfill contractual obligations [4]. Ultimately, the property responsibility for this failure can only be borne by the state.

\section{The Political Suggestions for the Coordinated Development}

\subsection{Expand transaction participants of the money market}

A series of new cross-market financial tools need to be developed vigorously to strengthen the coordinated development of the money market and capital market. The money market fund, an innovative form of money market trading instruments, is a nexus between the money market and the capital market. It serves both as institutional investor, to achieve liquidity management needs of low-risk, and as a way to conversion with capital market's securities investment fund, which constitutes a link between the money market and the capital market. 


\subsection{Accelerate development of credit asset securitization}

In order to accelerate the development of credit asset securitization, the linkages of money market and capital market are strengthened through a variety of products. From the assets of entity, credit assets are assets of commercial bank management, educational loan, project loan, housing mortgage loan, etc [5]. From the product form, credit assets are securities assets and can be exchanged outside the banking system. From the investment community, they can be institutional investors, and also be public investors. The following measures can be taken to accelerate the credit asset securitization: (1) an independent third party to form a new company specializing in credit securitization; (2) to build channels of credit assets to sell credit assets products; (3) to establish and improve the system, such as: government-led housing collateral insurance mechanism; tax incentives; to improve the financial regulatory system and so on.

\subsection{Specification development of capital market}

(1) To accelerate the change of mode of securities market development

The behaviors of the government in the market should be strictly defined, and the administrative functions in securities market of government should be placed under the market rules and institutional constraints. The things that ought to be done by the market are returned to the market, and social resources can be rationally and efficiently configured [6].

(2) Determine function orientation of the stock market as soon as possible

The function orientation of stock market is transformed from "financing type" to "resources configuration type", and it is vigorously promoted that the reform of the securities market system and the function of resource allocation. The development potential of the enterprise and professionalism are the standards of judgment.

(3) Develop the bond market vigorously

As the bond market is linked with the money market and financial market, its further development will enrich and improve internal direct financing instruments, making preoperative preparation for market manipulation of the central bank. First of all, the bond market should be unified, so that bond investors could use one account transacting international bond products, to achieve free flow of investors and different kinds of transaction vouchers. Secondly, actively reform bond issuance mechanism, so that more companies can customize the general issue bonds, increasing the supply of bond markets.

\section{References}

[1] Wang Xuekun. Research on the Coordination Development of Money Market and Capital Market in China [D], Hunan University. 2009.

[2] Yang Cuiyan. A Research on the Coordination of China's Money Market and Capital Market [D], Zhejiang University. 2009.

[3] Guo Liang. Research on harmony of Money Market and Capital Market [D], Tianjin University of Finance \& Economics. 2006.

[4] Xiao Tao. A study on the coordination development of the money market and capital market in China [D], Dongbei University of Finance \& Economics. 2012.

[5] Guo Rui. An empirical study on the coupling mechanism of China's money market and capital market [D], Northwest University. 2012.

[6] Bai Qinxian, Wang Yang. Research on the mechanism of communication and coordination between the money market and the capital market [J], Contemporary Finance \& Economics. 2007. 